\title{
Fluorogenic peptide substrates for carboxydipeptidase activity of cathepsin $B^{\star \star}$
}

\author{
Krystyna Stachowiak ${ }^{\bowtie}$, Monika Tokmina, Anna Karpińska, Renata Sosnowska and \\ Wiesław Wiczk
}

Faculty of Chemistry, University of Gdańsk, J. Sobieskiego 18, 80-952 Gdańsk, Poland

Received: 31 October, 2003; revised: 08 February, 2004; accepted: 17 February, 2004

Key words: cathepsin B, cystatins, fluorogenic substrate

Cathepsin B is a lysosomal cysteine protease exhibiting mainly dipeptidyl carboxypeptidase activity, which decreases dramatically above pH 5.5, when the enzyme starts acting as an endopeptidase. Since the common cathepsin B assays are performed at $\mathrm{pH} 6$ and do not distinguish between these activities, we synthesized a series of peptide substrates specifically designed for the carboxydipeptidase activity of cathepsin $B$. The amino-acid sequences of the $P_{5}-P_{1}$ part of these substrates were based on the binding fragments of cystatin $\mathrm{C}$ and cystatin SA, the natural reversible inhibitors of papain-like cysteine protease. The sequences of the $\mathbf{P}^{\prime}{ }_{1}-\mathbf{P}^{\prime}{ }_{2}$ dipeptide fragments of the substrates were chosen on the basis of the specificity of the $\mathbf{S}_{1}{ }_{1} \mathbf{S}^{\prime}{ }_{2}$ sites of the cathepsin $B$ catalytic cleft. The rates of hydrolysis by cathepsin $B$ and papain, the archetypal cysteine protease, were monitored by a continuous fluorescence assay based on internal resonance energy transfer from an Edans to a Dabcyl group. The fluorescence energy donor and acceptor were attached to the $\mathrm{C}$ - and the $\mathrm{N}$-terminal amino-acid residues, respectively. The kinetics of hydrolysis followed the

\footnotetext{
ॠ A preliminary report on the same subject was presented at the 26th European Peptide Symposium (reference: Nawrocka et al. (2000)).

This work was supported by the State Committee for Scientific Research, grant KBN-0298/ P04/2001/21 (Poland).

${ }^{\otimes}$ Corresponding author: phone (48) 5834 50367; fax: (48) 5834 10357; e-mail krysias@chemik.chem.univ.gda.pl

Abbreviations: Aad, L- $\alpha$-aminoadipic acid; Amc, 7-amino-4-methylcoumarin; Boc, t-butoxycarbonyl; Dabcyl, 4-(4-dimethylaminophenylazo)benzoyl; DCC, dicyclohexylcarbodiimide; DCM, dichloromethane; DMF, dimethylformamide; $\mathrm{Me}_{2} \mathrm{SO}$, dimethyl sulfoxide; E-64, trans-epoxysuccinyl-L-leucylamido(4-guanidino)butane; Edans, 5-[(2-aminoethyl)amino]naphtalene-1-sulfonic acid; Fmoc, 9-fluorenylmethoxycarbonyl; HOBt, 1-hydroxybenzotriazole; Nal, $\beta$-(2-naphthyl)-alanine; Pmc, 2,2,5,7,8-pentamethylchroman-6-sulfonyl; TFA, trifluoroacetic acid; Z, benzyloxycarbonyl; TBTU, 2-(1H-benzotriazole-1-yl)-1,1,3,3-tetramethyluronium tetrafluoroborate; TFE, 2,2,2-trifluoroethanol; TFFH, fluoro- $N, N, N^{\prime}, N^{\prime}$-tetramethylformamidinium hexafluorophosphate.
} 
Michaelis-Menten model. Out of all the examined peptides Dabcyl-R-L-V-G-FE(Edans) turned out to be a very good substrate for both papain and cathepsin $B$ at both pH 6 and pH 5. The replacement of Glu by Asp turned this peptide into an exclusive substrate for cathepsin B not hydrolyzed by papain. The substitution of Phe by Nal in the original substrate caused an increase of the specificity constant for cathepsin $\mathrm{B}$ at $\mathrm{pH} 5$, and a significant decrease at $\mathrm{pH}$ 6. The results of kinetic studies also suggest that Arg in position $\mathrm{P}_{4}$ is not important for the exopeptidase activity of cathepsin $B$, and that introducing Glu in place of Val in position $P_{2}$ causes an increase of the substrate preference towards this activity.

Cathepsin B is a papain-like cysteine protease, which is one of the major components of the lysosomal proteolytic system responsible for protein degradation and turnover (Wijffels, 1998; Mort \& Buttle, 1997). This protease also participates in specific cellular processes outside the lysosomes, including prohormone activation and antigen processing (Mort \& Buttle, 1997; Katunuma et al., 1998; Jutras \& Reudelhuber, 1999; Berdowasa \& Siewiński, 2000). Movement of cathepsin B and other lysosomal cathepsins towards the cell membrane or their secretion outside the cell may lead to degradation of the extracellular matrix. This process is usually pathological and contributes to the development of many serious human diseases such as cancer, arthritis, osteoporosis, Alzheimer's disease, multiple sclerosis, inflammation, etc. (Berdowasa \& Siewiński, 2000; Henskens et al., 1996; Keppler et al., 1996). It is assumed that in case of abnormal leakage of lysosomal cysteine proteases into the extracellular space the tissue cells are protected from proteolysis by natural inhibitors of these enzymes. The inhibitor responsible exclusively for deactivation of cathepsin B has not been identified yet. A large group of proteins called cystatins, which to a lesser or greater extent inhibit all cysteine proteases, has been described (Otto \& Schirmeister, 1997; Grzonka et al., 2001). Among them cystatin $\mathrm{C}$ is the most thoroughly investigated. It has been established that in many diseases caused by uncontrolled activity of cathepsins, including cathepsin B, the level of cystatin C decreases significantly (Berdowasa \& Siewiński, 2000; Henskens et al., 1996; Warwas \& Haczyńska, 1998; Grubb, 2000; Zore et al., 2001).
The structure of the cystatin $\mathrm{C}$ binding fragments as well as the specific environment of the catalytic pocket of cathepsin B might therefore be the key issues in the search for a selective substrate for this enzyme. Such a substrate, equipped with a sensitive marker, could become a useful tool in examining the mechanisms of cathepsin B malfunctions, especially in cases when there is a need for investigations of the enzyme activity in the presence of other proteases. It is well known that three different fragments of cystatin $\mathrm{C}$ take part in the inhibition of cysteine proteases. Its N-terminal segment Arg ${ }^{8}$-Leu-Val-Gly ${ }^{11}$ binds to the $\mathrm{S}_{4}-\mathrm{S}_{1}$ sites of the enzyme while $\operatorname{Trp}^{105}$ from the C-terminal loop of the inhibitor along with the dipeptide $\mathrm{Val}^{57}-\mathrm{Ala}^{58}$ from the central loop locate in the $\mathrm{S}_{1}{ }_{1} \mathrm{~S}_{3}{ }_{3}$ sites (Grzonka et al., 2001).

Cathepsin B (Fig. 1) unlike other proteases, possesses a unique structural element that influences its specific activity. It is the additional occluding loop $\mathrm{Ile}^{105}$-Pro ${ }^{126}$ which makes access to the $\mathrm{S}^{\prime}{ }_{1-} \mathrm{S}^{\prime}{ }_{2}$ sites of the catalytic pocket difficult (Musil et al., 1991; Illy et $a l$., 1997). The loop contains three crucial amino-acid residues $\mathrm{His}^{110}$, $\mathrm{His}^{111}$ and $\mathrm{Arg}^{116}$. At an acidic $\mathrm{pH}$, positively charged imidazole group of $\mathrm{His}^{110}$ forms a salt bridge with $\mathrm{Asp}^{22}$ which is located near the active center of the enzyme. Moreover, the loop is in contact with the remaining part of the protein by electrostatic interactions between $\mathrm{Arg}^{116}$ and $\mathrm{Asp}^{224}$. The partly occluded $\mathrm{S}^{\prime}{ }_{1} \mathrm{~S}^{\prime}{ }_{2}$ area of the catalytic pocket can accept only two amino-acid residues of the substrate. Additionally, the exopeptidase activity of cathepsin B observed under acidic conditions is thought to be a result of ionic interactions be- 
tween the C-terminal carboxyl group of the substrate and the positively charged His ${ }^{110}$ and His ${ }^{111}$ residues. Above $\mathrm{pH} 5.5$ the exopeptidase activity of cathepsin B decreases significantly and the enzyme starts to show endopeptidase activity simultaneously. It is supposed that this is the result of both deprotonation of the His ${ }^{110}$ residue and the increase of flexibility of the loop (Nägler et al., 1997; Quraishi et al., 1999).
C binding to this region of the enzyme requires conformational changes leading to the displacement of the occluding loop by the inhibitor (Nycander et al., 1998; Pavlova et al., 2000). The peptide segments of cystatin $\mathrm{C}$ responsible for the inhibition of cysteine proteases have already been used to develop substrates for these enzymes, however, none of them turned out to be selective for cathepsin B only (Lalmanach et al., 1995). Moreover,

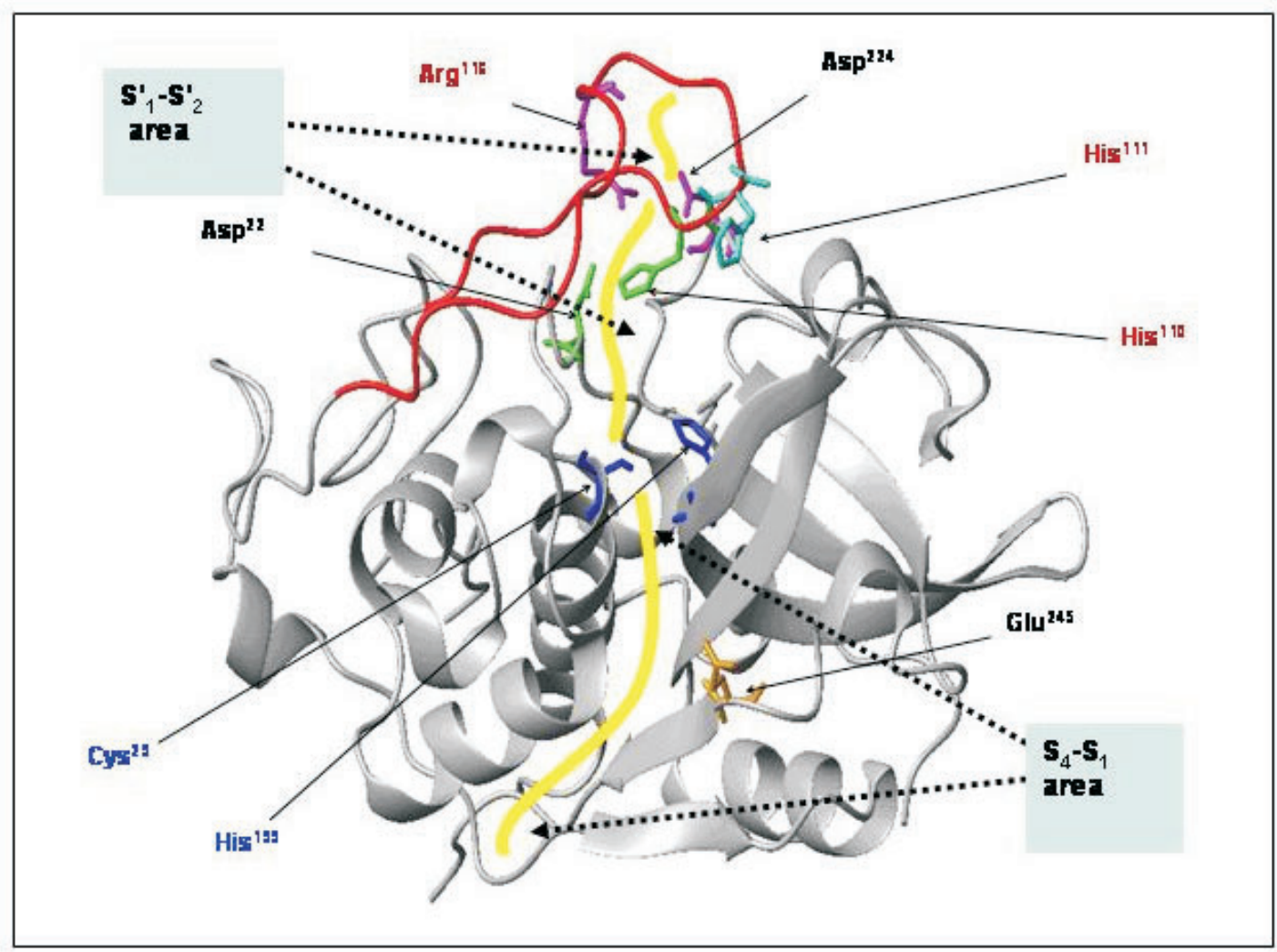

Figure 1. Conformation of cathepsin B (EC 3.4.22.1; 1HUC from PDB).

The main chain of the occluding loop (Ile ${ }^{105}-\mathrm{Pro}^{126}$ ) and symbols of its crucial residues are in red. The side chains forming salt bridges are in green ( $\mathrm{Asp}^{22} \leftrightarrow \mathrm{His}^{110}$ ) and pink ( $\mathrm{Arg}^{116} \leftrightarrow \mathrm{Asp}^{224}$ ). The yellow line indicates the catalytic cleft and navy blue colour shows the catalytic centre.

The binding mechanism of cystatin $\mathrm{C}$ to cathepsin B consists of two stages. Initially, the N-terminal fragment of the inhibitor interacts with the $\mathrm{S}_{4}-\mathrm{S}_{1}$ sites of the enzyme. The $\mathrm{S}_{1}{ }_{1-} \mathrm{S}_{2}{ }_{2}$ area of the catalytic pocket is covered by an occluding loop, therefore, cystatin the kinetics of hydrolysis of these substrates by cathepsin $\mathrm{B}$ was measured at $\mathrm{pH} 6$ when the catalytic cleft is probably partly open and the enzyme can act as an endopeptidase. Our research aims to find a selective substrate which would allow studying both the endo- 
peptidase and the carboxydipeptidase activity of cathepsin B. The design of the amino-acid sequence of the substrates' fragments on the left-hand side of the presumable digestion site $\left(\mathrm{P}_{5}-\mathrm{P}_{1}\right)$ was based on the results of cathepsin $\mathrm{B}$ inhibition by aldehyde derivatives contain-

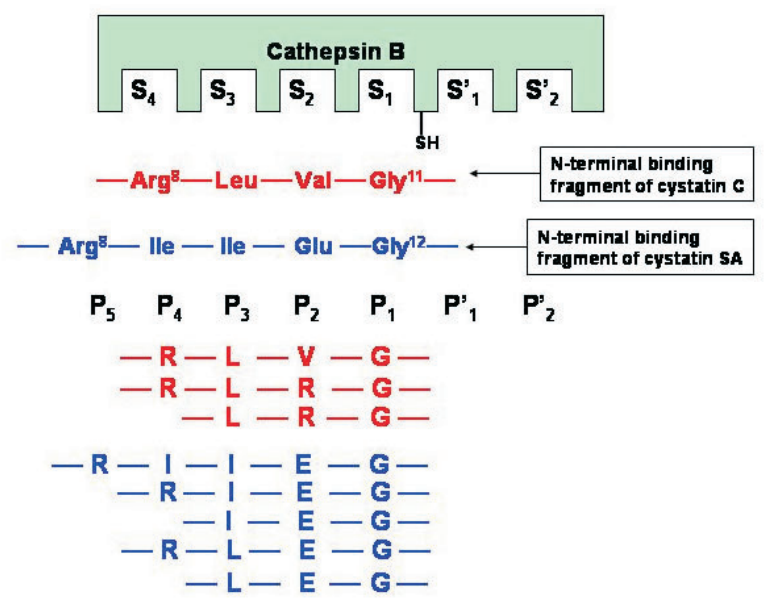

Figure 2. The amino-acid sequences of the $\mathbf{P}_{5}-\mathbf{P}_{1}$ fragments of substrates derived from the $\mathrm{N}$-terminal binding sequence of cystatin $C$ (red) and cystatin SA (blue).

Following the proposal by Schechter \& Berger (1967), the binding sites of the catalytic cleft of the enzyme and appropriate amino-acid residues of the substrate are represented by $\mathrm{S}_{4}, . . \mathrm{S}_{2}{ }_{2}$ and $\mathrm{P}_{4}, . . \mathrm{P}_{2}{ }_{2}$, respectively.

ing the N-terminal binding sequences of different cystatins (Stachowiak et al., 2001). We synthesized a series of internally quenched fluorescent peptides, which contain in positions $\mathrm{P}_{4}-\mathrm{P}_{1}$ or $\mathrm{P}_{5}-\mathrm{P}_{1}$ (Fig. 2) native or modified $\mathrm{N}$-terminal binding sequences of human cystatin C, Arg $^{8}{ }^{-}$Leu-Val-Gly $^{11}$, or human cystatin $\mathrm{SA}, \mathrm{Arg}^{8}$-Ile-Ile-Glu-Gly ${ }^{12}$, respectively. The $\mathrm{P}^{\prime}{ }_{1}-\mathrm{P}^{\prime}{ }_{2}$ part of the substrates (on the right-hand side of the presumable digestion site) contains dipeptides with dicarboxylic amino acid in position $\mathrm{P}_{2}^{\prime}$. A fluorescent donor (Edans) was anchored to the side chain carboxyl group. Retaining of the free $\alpha$-carboxyl group was important for preserving the carboxypeptidase activity of the enzyme. An energy acceptor (Dabcyl) was attached to the
N-terminus of the substrate. Preliminary results for cathepsin B only for seven substrates, with different concentrations of MeSO (3-5\%, v/v, depending on the solubility of the substrate) in the assay, have already been presented (Nawrocka et al., 2000). Because the value of the kinetic parameters significantly depends on MeSO concentration (Szabelski et al., 2001), in this paper we present the kinetic parameters of all the designed substrates hydrolyzed by cathepsin B and papain in buffers containing a constant MeSO concentration (5\%, v/v). The experiments for cathepsin $\mathrm{B}$ were performed at $\mathrm{pH}$ 6 and $\mathrm{pH} 4.5$ or 5 in the case of lower solubility of the substrate in more acidic conditions.

\section{MATERIALS AND METHODS}

Materials. E-64, Edans, bovine spleen cathepsin B (EC 3.4.22.1) and papain (EC 3.4.22.3) were purchased from Sigma. The commercial papain was purified as described previously (Blumberg et al., 1970). Z-PheArg-Amc and Fmoc-amino acids were purchased from Bachem. Wang resin was obtained from Novabiochem. Dabcyl was synthesized in our laboratory from 4-dimethylaminoaniline and $p$-aminobenzoic acid according to the procedure described in (Vogel, 1984).

Peptide synthesis. The intramolecularly quenched fluorogenic peptides: Dabcyl-peptidyl- $\mathrm{X}_{1}-\mathrm{X}_{2}$ (Edans), where $\mathrm{X}_{1}=\mathrm{Ile}$, Phe, Trp or $\mathrm{Nal}$ and $\mathrm{X}_{2}=\mathrm{Aad}$, Asp, Glu or D-Glu were synthesized partly on solid phase and partly in solution. The Dabcyl-peptide fragments of all substrates, apart from those that contained Glu, were prepared by Fmoc solid-phase peptide synthesis on $p$-benzyloxybenzyl alcohol resin (Wang resin), using the TBTU coupling method according to the typical manual peptide synthesis protocol (Dörner \& White, 2000, a). The side chain of Arg was protected by Pmc group. Dabcyl was introduced in the last coupling step. The cleavage of the final 
peptides from the resin and deprotection was accomplished using TFA/phenol/triisopropylsilane $/ \mathrm{H}_{2} \mathrm{O}$ (88:5:2:5, by vol.) (Reagent $B$ ). The Dabcyl-peptide fragments of the substrates containing Glu residue were synthesized on 2-chlorotrityl chloride resin according to the method described in (Dörner \& White, 2000, b). Tert-butyl group was applied to protect the $\gamma$-carboxyl group of Glu residue. Finally, fully protected peptides were cleaved from the resin by AcOH/TFE/DCM (1:1:8, by vol.) (Barlos et al., 1991). After removing from the resin, all peptides containing Dabcyl were purified by RP-HPLC on a Kromasil $5-\mu \mathrm{m}$ C8 semi-preparative column $(20 \times 250$ $\mathrm{mm})$ with solvent A ( $0.1 \%$ TFA in water) and solvent $\mathrm{B}(0.08 \% \mathrm{TFA}$ in $80 \%$ aqueous solution of acetonitrile) using four step gradient elution (from $0 \%$ to $20 \%$ B in $10 \mathrm{~min}$, from $20 \%$ to $40 \% \mathrm{~B}$ in $40 \mathrm{~min}$, from $40 \%$ to $80 \% \mathrm{~B}$ in 160 $\mathrm{min}$ and from $80 \%$ to $100 \% \mathrm{~B}$ in $190 \mathrm{~min}$ ) at a $16 \mathrm{ml} / \mathrm{min}$ flow rate and $223 \mathrm{~nm}$ detection wavelength. The purified products were identified by FAB-MS (quadrupole mass spectrometer TRIO3 VG MASSLAB).

The $\mathrm{X}_{1}-\mathrm{X}_{2}$ (Edans) fragments of the fluorogenic substrates were obtained as tert-butyl esters of dipeptides with Edans attached to the side chain carboxyl group (tert-butyl dipeptide(Edans) esters). The free side chain carboxyl group of the commercially available Fmoc-Glu-OBu ${ }^{t}$, Fmoc-Asp-OBu ${ }^{t}$ and Fmoc-D-Glu-OBut, and Z-Aad $(\mathrm{OH})-\mathrm{OBu}^{\mathrm{t}}$ obtained as previously described (Wenschuh et al., 1996; Liberek \& Kasprzykowska, 1987); was coupled with Edans using the TFFH method (Neises \& Steglick, 1978). Fmoc-X $_{2}$ (Edans)-OBu ${ }^{\mathrm{t}}$ (or Z-Aad(Edans)$\mathrm{OBu}^{t}$ ), after deprotection of the amino group, was coupled with corresponding Fmoc- $\mathrm{X}_{1}$ using the DCC/HOBt method (Bodanszky \& Bodanszky, 1984). Afterwards the Fmoc group was removed and the dipeptides $\left(\mathrm{X}_{1}-\mathrm{X}_{2}\right.$ (Edans)-OBu $\left.{ }^{\mathrm{t}}\right)$ were purified by RP-HPLC using a Kromasil $5-\mu \mathrm{m}$ C8 column with solvent A and solvent $\mathrm{C}(0.08 \% \mathrm{TFA}$ in $60 \%$ aqueous solution of isopropanol) using three step gradient elution (from $0 \%$ to $10 \% \mathrm{C}$ in $10 \mathrm{~min}, 20 \mathrm{~min}$ at $10 \%$ and from $10 \%$ to $40 \%$ $\mathrm{C}$ in $130 \mathrm{~min}$ ) at a $16 \rightarrow 6 \mathrm{ml} / \mathrm{min}$ flow rate. The relative molecular mass of the fluorescent dipeptide esters were confirmed by FAB MS. The obtained tert-butyl dipeptide(Edans) esters were joined with the Dabcyl-peptides using TFFH. Finally, the tert-butyl and Pmc groups were removed by Reagent $B$ and crude products were purified by RP-HPLC with solvent $A$ and solvent $B$ using three step gradient elution ( 30 min 0-30\% B, 60 min $30 \%$ B, $180 \mathrm{~min} 30-50 \% \mathrm{~B})$. The homogeneity and relative molecular mass of the obtained peptides were confirmed by analytical RP-HPLC using a Varian Vista 5500 HPLC system with a Kromasil KR 100-5C8 column $(4.6 \times 250$ $\mathrm{mm}$ ) with solvent A and solvent B using 60 min gradient elution from 0 to $100 \%$ B (1 $\mathrm{ml} / \mathrm{min}$ flow rate, $\lambda=223,360$ and $460 \mathrm{~nm}$ ) and mass spectrometry (FAB-MS).

Small amounts of each Dabcyl-peptide and dipeptide(Edans) ester were used to prepare standard probes for confirmation of the presumable enzymatic digestion site. This was achieved after cleavage of the protecting groups and purification using RP-HPLC. The compounds eluted from the column were lyophilized and identified by FAB-MS. The synthetic dipeptides $\mathrm{X}_{1}-\mathrm{X}_{2}$ (Edans) were also used for the determination of the fluorescence-concentration relationship.

Fluorescence measurements. Fluorescence was monitored on a Perkin-Elmer LS 50B spectrofluorimeter using the time drive option of the Fl WinLab software provided by the manufacturer. The excitation wavelength for Acm and Z-Phe-Arg-Acm was $380 \mathrm{~nm}$ whereas for $\mathrm{X}_{1}-\mathrm{X}_{2}$ (Edans) and Dabcyl-peptidyl- $\mathrm{X}_{1}-\mathrm{X}_{2}$ (Edans) it was $336 \mathrm{~nm}$. The observation wavelengths were $460 \mathrm{~nm}$ and $490 \mathrm{~nm}$ for aminocoumarin and Edans, respectively.

Cleavage site identification. All peptide substrates used for enzymatic assays were incubated for 0.5 to $120 \mathrm{~min}$ with activated cathepsin $\mathrm{B}(60.3 \mathrm{nM})$ or papain $(1.3 \mathrm{nM})$ in appropriate buffers. The substrates' concen- 
tration varied from 29.4 to $38.2 \mu \mathrm{M}$. The reactions were stopped by adding $3 \mathrm{ml}$ of methanol to precipitate the enzyme. The supernatants containing no digested peptides and (or) their proteolytic fragments were evaporated, dissolved in methanol and analyzed by HPLC on a Kromasil KR 100-5C8 column using 60 min linear $(0-60 \%)$ gradient of acetonitrile in $0.1 \%$ of TFA at a flow rate of $1 \mathrm{ml} / \mathrm{min}$ (detection wavelengths $\lambda=223,360$ and $460 \mathrm{~nm}$ ). A mixture of dissolved supernatants and synthetic standard peptides corresponding to the expected products of substrate hydrolysis were also chromatographed under the same conditions. Products from the enzymatic digestion were identified by comparing their retention times with those of the synthetic probes. In the case of an unexpected cleavage site, the additional digestion products were identified by FAB-MS analysis after being collected manually from the HPLC column.

Active site titration. The molar concentration of papain active sites was assessed by titration with E-64 according to the procedure described previously (Szabelski et al., 2001). For the determination of the molar concentration of cathepsin B active sites, the following method was applied. E-64 was incubated for $30 \mathrm{~min}$ in $0.5 \mathrm{M}$ sodium potassium phosphate buffer, $\mathrm{pH}=6$, containing $0.4 \mathrm{M}$ dithiothreitol, 0.1 M EDTA, 0.01\% Brij-35 and 5\% (v/v) MeSO. Then the substrate Z-Phe-ArgAmc was added to the final concentration of $127 \mu \mathrm{M}$. The reaction was stopped after 5 min.

Enzymatic assays. The method used for kinetic experiments with cathepsin B was slightly modified compared to the one described previously (Barrett et al., 1982). The enzyme $(0.4 \mu \mathrm{M})$ was preincubated at room temperature for $1.5 \mathrm{~h}$ in $0.5 \mathrm{M}$ sodium potassium phosphate buffer, $\mathrm{pH}=6$, containing 0.4 $\mathrm{M}$ dithiothreitol and 0.1 M EDTA. In the kinetic assays the reaction mixture contained $0.5 \mathrm{M}$ sodium potassium phosphate buffer $(\mathrm{pH}=6)$ or $0.1 / 0.05 \mathrm{M}$ sodium phosphate/ci- trate buffer $(\mathrm{pH}=4.5 ; 0.4 \mathrm{M}$ dithiothreitol, 0.1 M EDTA, 0.01\% Brij-35, 5\% (v/v) MeSO, from $5.1 \mathrm{nM}$ to $60.3 \mathrm{nM}$ cathepsin $\mathrm{B}$ and synthetic peptide substrate. The kinetic experiments with papain were generally performed as described in our previous paper (Szabelski et al., 2001), but using different papain (0.7 $\mathrm{nM}$ or $1.3 \mathrm{nM}$ ) and MeSO concentrations (constant, 5\%, v/v) in the reaction mixture. The concentration of the substrates during enzymatic assays varied in the range from 1 $\mu \mathrm{M}$ to $20 \mu \mathrm{M}$. The reactions were monitored for $15 \mathrm{~min}$ in the case of cathepsin B and 10 min for papain. The slope of the linear portion of the recorded fluorescence intensity increase (up to $5 \%$ substrate hydrolysis) was used to calculate the initial rate. The experimental data were applied to the Michaelis-Menten equation and the kinetic parameters $K_{\mathrm{m}}$ and $k_{\text {cat }}$ were calculated using the non-linear least squares method.

\section{RESULTS AND DISCUSSION}

\section{Hydrolysis of Dabcyl-R-L-V-G-X-X $1 \mathbf{X}_{\mathbf{2}}$ (Edans) by cathepsin $B$ and papain}

The first series of examined compounds (Table 1) contained the $\mathrm{Arg}^{8}$-Gly ${ }^{11}$ binding fragment of cystatin C. According to the previous investigation (Grzonka et al., 2001; Stachowiak et al., 2001) we expected the R-L-V-G fragment of the substrates to have a high affinity for the $\mathrm{S}_{4} \mathrm{~S}_{1}$ region of the cathepsin $\mathrm{B}$ catalytic cleft, whereas the $\mathrm{X}_{1}-\mathrm{X}_{2}$ dipeptide attached to the C-terminus of R-L-V-G should locate itself in the $\mathrm{S}^{\prime}{ }_{1}-\mathrm{S}^{\prime}{ }_{2}$ sites. The $\mathrm{X}_{1}$ position of the substrates contained Trp or Nal or Phe following the known preference of cathepsin B for hydrophobic residues in the $\mathrm{S}^{\prime}{ }_{1}$ site (Turk et al., 1998). The $\mathrm{X}_{2}$ position was occupied by dicarboxylic amino acids: Asp, Glu or Aad with the Edans group at their side chain carboxyl group. All the fluorogenic peptides presented in Table 1 were hydrolyzed by cathepsin B and papain at 
the Gly- $\mathrm{X}_{1}$ bond only, except for compound $\mathbf{V}$ which was not digested by papain. The specificity constants $\left(k_{\text {cat }} / K_{\mathrm{m}}\right)$ for substrates I-IV hydrolyzed by cathepsin B are much lower (several orders of magnitude) than those for papain (Table 1) in accord with observations by other authors (Lalmanach et al., 1995; Nägler et al., 1999; Portlando et al., 2000). group dimensions of the residue in position $\mathrm{X}_{1}$. For the substrate containing $\mathrm{Nal}$ in the $\mathrm{P}^{\prime}{ }_{1}$ position (III) the $k_{\text {cat }} / K_{\mathrm{m}}$ value at $\mathrm{pH} 5$ is about 16 times greater than at $\mathrm{pH} 6$, which is probably caused by the increase of both the affinity and the rate of catalysis. It is worth mentioning that Dabcyl-R-L-V-G-F-D(Edans) (V) is selective towards cathepsin B. The pep-

Table 1. Kinetic constants for hydrolysis of Dabcyl-R-L-V-G- $\mathrm{X}_{1}-\mathrm{X}_{2}$ (Edans) substrates by cathepsin B and papain.

\begin{tabular}{|c|c|c|c|c|c|c|c|c|c|}
\hline \multirow{2}{*}{ No. } & \multirow[b]{2}{*}{$-X_{1}-X_{2}$} & \multicolumn{4}{|c|}{ Cathepsin B } & \multicolumn{4}{|c|}{ Papain } \\
\hline & & $\mathrm{pH}$ & $\begin{array}{c}K_{\mathrm{m}} \\
(\mu \mathrm{M})\end{array}$ & $\begin{array}{c}k_{\mathrm{cat}} \times 10^{2} \\
\left(\mathrm{~s}^{-1}\right)\end{array}$ & $\begin{array}{c}k_{\mathrm{cat}} / K_{\mathrm{m}} \\
\left(\mathrm{mM}^{-1} \mathrm{~s}^{-1}\right)\end{array}$ & $\mathrm{pH}$ & $\begin{array}{c}K_{\mathrm{m}} \\
(\mu \mathrm{M})\end{array}$ & $\begin{array}{c}k_{\mathrm{cat}} \\
\left(\mathrm{s}^{-1}\right)\end{array}$ & $\begin{array}{c}k_{\mathrm{cat}} / K_{\mathrm{m}} \\
\left(\mathrm{mM}^{-1} \mathrm{~s}^{-1}\right)\end{array}$ \\
\hline I & $-F-E$ & $\begin{array}{l}6.0 \\
5.0\end{array}$ & $\begin{array}{l}2.2 \pm 0.7 \\
3.5 \pm 0.6\end{array}$ & $\begin{array}{l}16 \pm 2 \\
43 \pm 2\end{array}$ & $\begin{array}{c}72.7 \\
122.9\end{array}$ & 6.8 & $4.1 \pm 1.0$ & $18.74 \pm 1.7$ & 4571 \\
\hline II & $-W-E$ & $\begin{array}{l}6.0 \\
5.0\end{array}$ & $\begin{array}{l}7.8 \pm 1.5 \\
4.7 \pm 0.7\end{array}$ & $\begin{array}{c}4.1 \pm 0.4 \\
34 \pm 3\end{array}$ & $\begin{array}{c}5.3 \\
72.3\end{array}$ & 6.8 & $2.3 \pm 0.5$ & $2.64 \pm 0.19$ & 1148 \\
\hline III & -Nal-E & $\begin{array}{l}6.0 \\
5.0\end{array}$ & $\begin{array}{l}3.8 \pm 1.2 \\
1.0 \pm 0.4\end{array}$ & $\begin{array}{c}3.3 \pm 0.5 \\
14 \pm 1\end{array}$ & $\begin{array}{c}8.7 \\
140.0\end{array}$ & 6.8 & $2.5 \pm 0.5$ & $4.04 \pm 0.16$ & 1616 \\
\hline IV & -F-Aad & $\begin{array}{l}6.0 \\
4.5\end{array}$ & $\begin{array}{l}2.9 \pm 0.6 \\
5.9 \pm 4.5\end{array}$ & $\begin{array}{c}22 \pm 2 \\
53 \pm 26\end{array}$ & $\begin{array}{l}75.9 \\
89.8\end{array}$ & 6.5 & $7.7 \pm 2.5$ & $9.62 \pm 1.66$ & 1249 \\
\hline V & $-F-D$ & $\begin{array}{l}6.0 \\
4.5\end{array}$ & $\begin{array}{r}3.0 \pm 0.7 \\
14.5 \pm 8.3\end{array}$ & $\begin{array}{c}20 \pm 1 \\
129 \pm 61\end{array}$ & $\begin{array}{l}66.7 \\
89.7\end{array}$ & 6.5 & & Not hydrolyzed & \\
\hline
\end{tabular}

This is the consequence of lower $k_{\text {cat }}$ values, which in turn seem to result from the poor access of the substrates not only to the $\mathrm{S}^{\prime}{ }_{1} \mathrm{~S}^{\prime}{ }_{2}$ area of the catalytic cleft but also to the catalytic center of cathepsin $\mathrm{B}$, due to the presence of the additional occluding loop. Similar $K_{\mathrm{m}}$ values for the peptides examined suggest that the amino-acid residues placed on the left of the digestion site mainly determine the affinity of the substrates for both enzymes. It is interesting that for cathepsin $B$ the Dabcyl-R-L-V-G-X ${ }_{1}-\mathrm{E}(\mathrm{Edans}) \quad$ substrates (I-III; where $\mathrm{X}_{1}$ represents Phe or Trp or Nal) exhibit the highest $k_{\text {cat }} / K_{\mathrm{m}}$ value at lower $\mathrm{pH}$. The access of the substrates to the $\mathrm{S}_{1}{ }^{\prime}-\mathrm{S}_{2}{ }^{\prime}$ sites at $\mathrm{pH} 5$ should be more difficult than at $\mathrm{pH} 6$ due to the stiffening of the occluding loop by the salt bridge between His ${ }^{110}$ and $\mathrm{Asp}^{22}$ which is broken at $\mathrm{pH}$ around 5.5. The ratio of specificity constants at $\mathrm{pH} 5$ and 6 increases with the increase of the side tides Dabcyl-R-L-V-G-F-X ${ }_{2}$ (Edans), where $\mathrm{X}_{2}$ represents Asp or Glu or Aad (V, I, IV), were designed to investigate the influence of the side chain size of the $\mathrm{X}_{2}$ residue with an Edans group attached on the kinetics of hydrolysis. Because of its bulkiness, the Edans group can hinder location of the substrates to the $\mathbf{S}^{\prime}{ }_{1}{ }^{-} \mathbf{S}_{2}{ }_{2}$ region. It was supposed that elongation of the side chain of the substrate will lead the Edans group out of the catalytic cleft of cathepsin B and facilitate the interaction of the substrate C-terminal carboxyl group with His $^{111}$ of $\mathrm{S}_{2}^{\prime}$ site. Such interactions are important for the carboxydipeptidase activity of the enzyme, which should be expressed by an increase in the specificity constant $\left(k_{\text {cat }} / K_{\mathrm{m}}\right)$. However, for the three substrates mentioned above the $k_{\text {cat }} / K_{\mathrm{m}}$ values for cathepsin B are similar. Peptides I and IV are also good substrates for papain, but Dabcyl-R-L-VG-F-E(Edans) was the best one among all in- 
vestigated. Thus, surprisingly, shortening of the side chain in the $\mathrm{C}$-terminal amino acid by one methylene group only caused a complete lack of activity by papain (compare peptides I and V). In the present moment we are not able to give a reasonable explanation of this finding.

\section{Hydrolysis of Dabcyl-R-L-R-G-F-X ${ }_{2}$ (Edans) and Dabcyl-L-R-G-F-X $\mathbf{X}_{2}$ (Edans) by cathepsin $B$ and papain}

Table 2 shows the kinetic parameters for the fluorogenic substrates derived from Dabcyl- the substrate used for the standard assay of papain family enzymes Z-Phe-Arg-Amc into one that is selective for cathepsin B (Z-Arg-Arg-Amc). Unfortunately, this did not occur in the case of our substrates. All the peptides presented in Table 2 were cleaved by cathepsin B at the Gly-Phe bond only, whereas they where cleaved by papain at the Gly-Phe or Arg-Gly bond. Papain hydrolyzed all substrates of this series, similar to substrates I-IV (Table 1), with a higher efficiency than cathepsin B. The specificity constant for cathepsin B was also not improved (compare peptides VI and I). Shortening of

Table 2. Kinetic constants for hydrolysis of Dabcyl-R-L-R-G-F-X ${ }_{2}$ Edans) and Dabcyl-L-R-G-F$\mathrm{X}_{2}$ (Edans) by cathepsin $\mathrm{B}$ and papain

\begin{tabular}{|c|c|c|c|c|c|c|c|c|c|}
\hline \multirow{2}{*}{ No. } & \multirow{2}{*}{$\begin{array}{l}\text { Amino acid } \\
\text { sequence of } \\
\text { the substrates }\end{array}$} & \multicolumn{4}{|c|}{ Cathepsin B } & \multicolumn{4}{|c|}{ Papain* } \\
\hline & & $\mathrm{pH}$ & $\begin{array}{c}K_{\mathrm{m}} \\
(\mu \mathrm{M})\end{array}$ & $\begin{array}{c}k_{\mathrm{cat}} \times 10^{2} \\
\left(\mathrm{~s}^{-1}\right)\end{array}$ & $\begin{array}{c}k_{\mathrm{cat}} / K_{\mathrm{m}} \\
\left(\mathrm{mM}^{-1} \mathrm{~s}^{-1}\right)\end{array}$ & $\mathrm{pH}$ & $\begin{array}{c}K_{\mathrm{m}} \\
(\mu \mathrm{M})\end{array}$ & $\begin{array}{c}k_{\mathrm{cat}} \\
\left(\mathrm{s}^{-1}\right)\end{array}$ & $\begin{array}{c}k_{\text {cat }} / K_{\mathrm{m}} \\
\left(\mathrm{mM}^{-1} \mathrm{~s}^{-1}\right)\end{array}$ \\
\hline VI & $\begin{array}{c}\text {-R-L-R-G- } \\
\text {-F-E }\end{array}$ & $\begin{array}{l}6.0 \\
4.5\end{array}$ & $\begin{array}{l}5.3 \pm 0.7 \\
3.5 \pm 1.0\end{array}$ & $\begin{array}{c}7.8 \pm 0.5 \\
21 \pm 3\end{array}$ & $\begin{array}{l}14.7 \\
60.0\end{array}$ & 6.8 & $2.9 \pm 0.8$ & $2.84 \pm 0.28$ & 979 \\
\hline VII & $\begin{array}{c}\text {-R-L-R-G- } \\
\text {-F-D-E }\end{array}$ & $\begin{array}{l}6.0 \\
5.0\end{array}$ & $\begin{array}{l}3.6 \pm 0.5 \\
2.8 \pm 0.9\end{array}$ & $\begin{array}{l}4.1 \pm 0.2 \\
2.3 \pm 0.3\end{array}$ & $\begin{array}{c}11.4 \\
8.2\end{array}$ & 6.8 & $3.2 \pm 1.0$ & $2.81 \pm 0.31$ & 878 \\
\hline VIII & $\begin{array}{c}\text {-L-R-G- } \\
\text {-F-E }\end{array}$ & $\begin{array}{l}6.0 \\
5.0\end{array}$ & $\begin{array}{l}3.7 \pm 0.6 \\
8.2 \pm 2.1\end{array}$ & $\begin{array}{c}9.2 \pm 0.5 \\
42 \pm 7\end{array}$ & $\begin{array}{l}24.9 \\
51.2\end{array}$ & 6.8 & $5.1 \pm 0.9$ & $5.27 \pm 0.42$ & 1033 \\
\hline IX & $\begin{array}{l}\text {-L-R-G- } \\
\text {-F-D-E }\end{array}$ & $\begin{array}{l}6.0 \\
5.0 \\
\end{array}$ & $\begin{array}{l}4.6 \pm 0.6 \\
7.8 \pm 1.0\end{array}$ & $\begin{array}{l}2.7 \pm 0.1 \\
3.8 \pm 0.3\end{array}$ & $\begin{array}{l}5.9 \\
4.9 \\
\end{array}$ & 6.8 & $7.3 \pm 1,7$ & $10.4 \pm 1.3$ & 1425 \\
\hline
\end{tabular}

${ }^{*}$ Apparent $K_{\mathrm{m}}$ and $k_{\text {cat }}$ values (two alternative digestion sites).

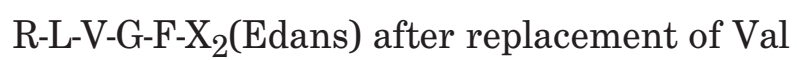
by Arg. In this series of substrates $\mathrm{E}$ or D-E was introduced as the $\mathrm{X}_{2}$ residue. The purpose of the substitution at the $\mathrm{P}_{2}$ position was to examine whether the presence of Arg instead of Val could turn the substrates towards being more selective for cathepsin B. It is well established that this enzyme prefers not only hydrophobic but also basic residues at the $\mathrm{P}_{2}$ position of the substrate due to the presence of $\mathrm{Glu}^{245}$ (Fig. 1) instead of $\mathrm{Ser}^{205}$ (as in the case of papain) at the $\mathrm{S}_{2}$ site (Turk et al., 1998). Moreover, the introduction of Arg in the place of a hydrophobic residue changed the amino-acid sequence of DabcylR-L-R-G-F-X ${ }_{2}$ (Edans) by the N-terminal Arg changed the kinetic parameters insignificantly (compare peptides VI, VII with VIII, IX). This suggests that Arg in $\mathrm{P}_{4}$ position is not essential for the exopeptidase activity of cathepsin B. Peptides VII and IX were designed in order to examine how the reverse configuration of the C-terminal residue influences the kinetic parameters, in view of the very strict and unflexible environment of the $\mathrm{S}_{2}{ }_{2}$ site of cathepsin B, particularly at a lower $\mathrm{pH}$. The results presented in Table 2 show that in the case of cathepsin B the change of 
glutamic acid configuration decreased the specificity constant, especially under more acidic conditions. For instance DabcylL-R-G-F-D-E(Edans) shows a 10 times lower $k_{\text {cat }} / K_{\mathrm{m}}$ value at $\mathrm{pH} 5$ than Dabcyl-LR-G-F-E(Edans) due to the decrease in $k_{\text {cat }}$ value. In the case of papain, the apparent $k_{\text {cat }} / K_{\mathrm{m}}$ values for peptides VII and IX do not change very much compared to peptides VI and VIII, respectively.

\section{Hydrolysis of Dabcyl-R-I-I-E-G-I-E(Edans) and its derivatives by cathepsin $B$ and papain}

In Table 3 the kinetic parameters for hydrolysis of substrates containing the I-E dipeptide on the right from the presumable diges- azapeptide inhibitor which was highly potent and selective for cathepsin B (Wieczerzak et al., 2002). The $\mathrm{P}_{5}-\mathrm{P}_{1}$ part of peptides $\mathrm{X}-\mathbf{X I V}$ was based on the N-terminal binding fragment of cystatin SA ( $\left.\mathrm{Arg}^{8}{ }^{-} \mathrm{Gly}^{12}\right)$. We introduced the amino-acid sequence R-I-I-E-G (without or with some modifications) to our fluorogenic peptides expecting that this fragment would turn our substrates into more selective ones towards cathepsin $\mathrm{B}$. The effect of Glu in $\mathrm{P}_{2}$ position on the kinetics of hydrolysis at different $\mathrm{pH}$ was also examined because the first substrates which have been proposed for testing the carboxydipeptidase activity of cathepsin B possessed this aminoacid residue in this position and were characterized by $\mathrm{pH}$ optima around 4.5 (Pohl et al., 1987).

Table 3. Kinetic constants for hydrolysis by cathepsin B and papain of substrates derived from Dabcyl-R-I-I-E-G-I-E(Edans)

\begin{tabular}{|c|c|c|c|c|c|c|c|c|c|}
\hline \multirow{2}{*}{ No. } & \multirow{2}{*}{$\begin{array}{l}\text { Amino acid } \\
\text { sequence of the } \\
\text { substrates }\end{array}$} & \multicolumn{4}{|c|}{ Cathepsin B } & \multicolumn{4}{|c|}{ Papain } \\
\hline & & $\mathrm{pH}$ & $\begin{array}{c}K_{\mathrm{m}} \\
(\mu \mathrm{M})\end{array}$ & $\begin{array}{c}k_{\text {cat }} \times 10^{2} \\
\left(\mathrm{~s}^{-1}\right)\end{array}$ & $\begin{array}{c}k_{\mathrm{cat}} / K_{\mathrm{m}} \\
\left(\mathrm{mM}^{-1} \mathrm{~s}^{-1}\right)\end{array}$ & $\mathrm{pH}$ & $\begin{array}{c}K_{\mathrm{m}} \\
(\mu \mathrm{M})\end{array}$ & $\begin{array}{l}k_{\text {cat }} \\
\left(\mathrm{s}^{-1}\right)\end{array}$ & $\begin{array}{c}k_{\mathrm{cat}} / \mathrm{K}_{\mathrm{m}} \\
\left(\mathrm{mM}^{-1} \mathrm{~s}^{-1}\right)\end{array}$ \\
\hline \multirow{2}{*}{$\mathbf{X}$} & \multirow{2}{*}{$\begin{array}{c}\text {-R-I-I-E-G- } \\
\text {-I-E }\end{array}$} & 6.0 & \multicolumn{3}{|c|}{ Not hydrolyzed } & \multirow{2}{*}{6.5} & \multirow{2}{*}{$13.2 \pm 10.1$} & \multirow{2}{*}{$1.1 \pm 0.5$} & \multirow{2}{*}{83.3} \\
\hline & & 4.5 & $5.5 \pm 1.5$ & $1.0 \pm 0.1$ & 1.8 & & & & \\
\hline $\mathbf{X I}$ & $\begin{array}{c}\text {-R-I-E-G- } \\
\text {-I-E } \\
\end{array}$ & $\begin{array}{l}6.0 \\
4.5 \\
\end{array}$ & $\begin{array}{l}3.7 \pm 0.8 \\
4.6 \pm 0.7\end{array}$ & $\begin{array}{l}0.29 \pm 0.02 \\
0.10 \pm 0.01 \\
\end{array}$ & $\begin{array}{l}0.8 \\
0.2 \\
\end{array}$ & 6.5 & \multicolumn{2}{|r|}{ Not hydrolyzed } & \\
\hline \multirow[t]{2}{*}{ XII } & \multirow{2}{*}{$\begin{array}{c}\text {-I-E-G- } \\
\text {-I-E }\end{array}$} & 6.0 & & t hydrolyzed & & \multirow[t]{2}{*}{6.5} & \multirow{2}{*}{\multicolumn{2}{|c|}{ Not hydrolyzed }} & \\
\hline & & 4.5 & $4.0 \pm 1.0$ & $1.31 \pm 0.09$ & 3.3 & & & & \\
\hline XIII & $\begin{array}{c}\text {-R-L-E-G- } \\
\text {-I-E }\end{array}$ & $\begin{array}{l}6.0 \\
4.5 \\
\end{array}$ & $\begin{array}{l}3.4 \pm 0.7 \\
4.9 \pm 1.3\end{array}$ & $\begin{array}{c}0.45 \pm 0.03 \\
1.8 \pm 0.2\end{array}$ & $\begin{array}{l}1.3 \\
3.7 \\
\end{array}$ & 6.5 & $9.3 \pm 2.7$ & $4.8 \pm 0.7$ & 516 \\
\hline \multirow{2}{*}{ XIV } & \multirow{2}{*}{$\begin{array}{c}\text {-L-E-G- } \\
\text {-I-E }\end{array}$} & 6.0 & & t hydrolyzed & & \multirow{2}{*}{6.5} & \multirow{2}{*}{\multicolumn{2}{|c|}{ Not hydrolyzed }} & \\
\hline & & 4.5 & $5.6 \pm 1.1$ & $2.6 \pm 0.3$ & 4.6 & & & & \\
\hline XV & $\begin{array}{c}\text {-L-R-G- } \\
-\mathrm{I}-\mathrm{E}\end{array}$ & $\begin{array}{l}6.0 \\
4.5 \\
\end{array}$ & $\begin{array}{l}6.6 \pm 1.8 \\
6.0 \pm 1.0 \\
\end{array}$ & $\begin{array}{l}4.7 \pm 0.5 \\
3.4 \pm 0.2\end{array}$ & $\begin{array}{l}7.1 \\
5.7\end{array}$ & 6.5 & $5.8 \pm 2.2$ & $2.6 \pm 0.4$ & 448 \\
\hline
\end{tabular}

tion site are collected. In this series we used Ile in $\mathrm{P}^{\prime}{ }_{1}$ position in order to check whether this residue improves the specificity constant of the substrates in comparison with peptides I-IX containing an aromatic amino acid in this position. The specific irreversible inhibitor CA074 of cathepsin B contains an Ile residue fitting very well into the $\mathbf{S}^{\prime}{ }_{1}$ space in the crystal complex of this enzyme with the inhibitor (Yamamoto et al., 2000). The Ile residue was also present in $\mathrm{P}^{\prime}{ }_{1}$ position of an
The peptides listed in Table 3 were digested by cathepsin $\mathrm{B}$ at the expected bond only (Gly-Ile) but with significantly lower $k_{\text {cat }} / K_{\mathrm{m}}$ values than substrates I-VI and VIII. Comparison of the data obtained for peptides VIII and $\mathbf{X V}$ led us to the conclusion that the decreasing of the specificity constant in this series of compounds arose, contrary to our expectations, due to the replacement of the aromatic amino-acid residue in position $\mathrm{P}^{\prime}{ }_{1}$ by Ile. This confirmed the observation that the 
interaction between the enzyme and the peptide substrate depends on the whole of the substrate structure, and the preferences of the $\mathbf{S}_{4}-\mathbf{S}_{2}{ }_{2}$ sites of the enzyme catalytic cleft for particular amino-acid residues are not necessarily additive (Hilaire et al., 1999). However, the fact that peptides X, XII and XIV were not hydrolyzed by cathepsin B at $\mathrm{pH} 6$, while papain did not digest peptides $\mathbf{X I}$, XII and XIV is worth noticing. This suggests that the introduction of a Glu residue in $\mathrm{P}_{2}$ combined with certain modifications in the $\mathrm{P}^{\prime}{ }_{1}-\mathrm{P}_{2}{ }_{2}$ part (for example Nal-E, F-D or Nal-D instead of I-E) may turn our substrates towards selective for the cathepsin B carboxydipeptidase activity only. The kinetic data for peptides X-XIV show that residues beyond the $\mathrm{P}_{3}$ position are not essential for the exopeptidase activity of cathepsin B, which is consistent with the conclusion derived from Table 2 . The substitution of Ile by Leu at $\mathrm{P}_{3}$ slightly improves the $k_{\text {cat }} / K_{\mathrm{m}}$ values for cathepsin $B$, especially for peptide XIII (comparing with XI) at $\mathrm{pH}$ 4.5. Peptides $\mathbf{X}$ and XII were hydrolyzed by papain at the Gly-Ile bond, whereas compound XV was cleaved between the Arg and Gly residues. The peptides digested by papain were better substrates for this enzyme than for cathepsin B.

\section{CONCLUDING REMARKS}

Summarizing, the peptides designed on the basis of cystatin $\mathrm{C}$ N-terminal fragment were definitely better substrates for cathepsin B compared to peptides derived from the cystatin SA N-terminal binding fragment. The best selective substrate of cathepsin B at pH 6 and 4.5 was Dabcyl-R-L-V-G-F-D(Edans). But it seems that the Arg residue could be omitted in this sequence without causing a decrease of this substrate's sensitivity. Moreover, the replacement of Phe by $\mathrm{Nal}$ and (or) Val by Glu residue may turn this substrate into one selective for cathepsin $B$ in acidic conditions and make it a convenient tool for testing exclusively the dipeptidyl carboxypeptidase activity of this enzyme. Since cathepsin $\mathrm{B}$ acts in natural conditions mainly as an exopeptidase, we hope that our fluorogenic substrates after the proposed modifications could be used to determine the specific activity of this enzyme directly in complex biological systems, such as crude tissue extracts or intact cells and its components. Our findings can also help to design specific reversible inhibitors of cathepsin B that would selectively inhibit the exopeptidase or the endopeptidase activity of this enzyme.

\section{R E F E R E N C E S}

Barlos K, Chatzi O, Gatos D, Stavropoulos G. (1991) 2-Chlorotrityl chloride resin. Studies on anchoring of Fmoc-amino acids and peptide cleavage. Int $J$ Pept Protein Res.; 37: $513-20$

Barrett AJ, Kembahavi AA, Brown MA, Kirschke H, Knight CG, Tamai M, Hanada K. (1982) L-Trans-epoxysuccinyl-leucylamido(4-guanidino)butane (E-64) and its analogues as inhibitors of cysteine proteinases including cathepsins B, H and L. Biochem J.; 201: 189-98.

Berdowska I, Siewiński M. (2000) Rola katepsyn cysteinowych oraz ich inhibitorów w procesach fizjologicznych i nowotworowych. Post Biochem.; 46: 73-84 (in Polish).

Blumberg S, Schechter I, Berger A. (1970) The purification of papain by affinity chromatography. Eur J Biochem.; 15: 97-102.

Bodanszky M, Bodanszky A. (1984) The Practice of Peptide Chemistry, pp 143. Springer-Verlag, New York.

Dörner B, White P. (2000) Synthesis Notes. In Novabiochem Catalog. (a) pp P33, (b) pp S15. CN Bioscience, Inc., An Affiliate of Merck KgoA, Darmstadt, Germany. 
Grubb A. (2000) Cystatin C - properties and use as diagnostic marker. Adv Clin Chem.; 35: 63-99.

Grzonka Z, Jankowska E, Kasprzykowski F, Kasprzykowska R, Łankiewicz L, Wiczk W, Wieczerzak E, Ciarkowski J, Drabik P, Janowski R, Kozak M, Jaskólski M, Grubb A. (2001) Structural studies of cysteine proteases and their inhibitors. Acta Biochim Polon.; 48: 1-20.

Henskens YMC, Veerman ECI, Amerongen AV. (1996) Cystatins in health and disease. Biol Chem Hoppe-Seyler.; 377: 71-86.

Hilaire Ph, Willert M, Juliano M, Juliano L, Meldal M. (1999) Fluorescence-quenched solid phase combinatorial libraries in the characterization of cysteine protease substrate specificity. J Comb Chem.; 1: 509-23.

Illy C, Quraishi O, Wang J, Purisima E, Vernet T, Mort J. (1997) Role of the occluding loop in cathepsin B activity. $J$ Biol Chem.; 272: 1197-202.

Jutras I, Reudelhuber TL. (1999) Prorenin processing by cathepsin $\mathrm{B}$ in vitro and in transfected cells. FEBS Lett.; 443: 48-52.

Katunuma N, Matsunaga Y, Matsui A, Kakegawa H, Endo K, Inubushi T, Saibara T, Ohba Y, Kakiuchi T. (1998) Novel physiological functions of cathepsins $\mathrm{B}$ and $\mathrm{L}$ on antigen processing and osteoclastic bone resorption. Adv Enzyme Regul.; 38: 235-51.

Keppler D, Sameni M, Moin K, Mikkelsen T, Diglio CA, Sloane BF. (1996) Tumor progression and angiogenesis. Biochem Cell Biol.; 74: $799-810$.

Lalmanach G, Serveau C, Brillard-Bourdet M, Chagas J, Mayer R, Juliano L, Gauthier F. (1995) Conserved cystatin segments as models for designing specific substrates and inhibitors of cysteine proteinases. J Protein Chem.; 14: 645-53.

Liberek B, Kasprzykowska R. (1987) Oxidation products of L-lysine derivatives as starting materials for peptide synthesis and for the preparation of homoglutamic acid, homoglutamine and homoisoglutamine. Int $J$ Peptide Protein Res.; 30: 522-32.
Mort JS, Buttle DJ. (1997) Cathepsin B. $J$ Biochem Cell Biol.; 29: 715-20.

Musil D, Zucic D, Turk D, Engh RA, Mayr I, Huber R, Popovic T, Turk V, Towatari T, Katunuma N, Bode W. (1991) The refined $2.15 \AA$ X-ray crystal structure of human liver cathepsin B: the structural basis for its specificity. EMBO J.; 10: 2321-30.

Nägler D, Storer A, Portaro F. Carmona E, Juliano L, Menard R. (1997) Major increase in endopeptidase activity of human cathepsin B upon removal of occluding loop contacts. Biochemistry.; 36: 12608-15.

Nägler D, Tam W, Storer A, Krupa J, Mort J, Ménard R. (1999) Interdependency of sequence and positional specificities for cysteine proteases of the papain family. Biochemistry.; 38: 4868-74.

Nawrocka M, Tokmina M, Wiczk W, Stachowiak K. (2001) Intramolecularly quenched fluorogenic peptide substrates for cathepsin B. In Peptides 2000, Proc. of 26th European Peptide Symposium. Martinez J, Fehrentz JA, eds, pp 566-7. EDK, Paris.

Neises B, Steglick W. (1978) Simple methods for the esterification of carboxylic acids. Angew Chem Int Ed Engl.; 17: 523-54.

Nycander M, Estrada S, Mort JS, Abrahamson M, Björk I. (1998) Two-step mechanism of inhibition of cathepsin $\mathrm{B}$ by cystatin $\mathrm{C}$ due to displacement of the proteinase occluding loop. FEBS Lett.; 422: 61-4.

Otto HH, Schirmeister T. (1997) Cysteine proteases and their inhibitors. Chem Rev.; 97: 133-72.

Pavlova A, Krupa J, Mort J, Abrahamson M, Bjork I. (2000) Cystatin inhibition of cathepsin $B$ requires dislocation of the proteinase occluding loop. Demonstration by release of loop anchoring through mutation of His110. FEBS Lett.; 487: 156-60.

Pohl J, Davinic S, Blaha I, Strop P, Kostka V. (1987) Chromophoric and fluorophoric peptide substrates cleaved through the dipeptidyl carboxypeptidase activity of cathepsin B. Anal Biochem.; 95: 228-35. 
Portlando F, Santos A, Cezari M, Juliano M, Juliano L, Carmona E. (2000) Probing the specificity of cysteine proteinases at subsites remote from the active site: analysis of $\mathrm{P}_{4}$, $\mathrm{P}_{3}, \mathrm{P}_{2}{ }^{\prime}$ and $\mathrm{P}_{3}{ }^{\prime}$ variations in extended substrates. Biochem J.; 347: 123-9.

Quraishi O, Nägler D, Fox T, Sivaraman J, Cygler M, Mort J, Storer A. (1999) The occluding loop in cathepsin $\mathrm{B}$ defines the $\mathrm{pH}$ dependence of inhibition by its propeptide. Biochemistry.; 38: 5017-23.

Stachowiak K, Tokmina M, Kasprzykowska R, Kasprzykowski F, Wiczk W. (2001) Inhibition of cathepsin B by aldehyde derivatives of cystatins N-terminal binding fragments. In Programme and abstracts of IPS International Conference on Protease Inhibitors, $\mathrm{p}$ 185. Munich, Germany.

Szabelski M, Stachowiak K, Wiczk W. (2001) Influence of $\mathrm{Me}_{2} \mathrm{SO}$ and incubation time on papain activity studied using fluorogenic substrates. Acta Biochim Polon.; 48: 995-1002.

Schechter I, Berger A. (1967) On the size of the active site in proteases. I. Papain. Biochem Biophys Res Commun.; 27: 157-162.

Turk D, Guncar G, Podobnik M, Turk B. (1998) Revised definition of substrate binding sites of papain-like cysteine proteases. Biol Chem.; 379: 137-47.

Vogel A. (1984) Textbook of Practical Organic Chemistry. pp 611-612, WNT, Warsaw (in Polish).
Warwas M, Haczyńska H. (1998) Rola cystatyn w procesie nowotworowym i jego diagnostyce. Post Hig Med Dośw.; 52: 515-26 (in Polish).

Wenschuh H, Beyermann M, Winter R, Bienert M, Ionescu D, Carpino LA. (1996) Fmoc amino acid fluorides in peptide synthesis extension of the method to extremely hindered amino acids. Tetrahedron Lett.; 37: 5483-5.

Wieczerzak E, Drabik P, Łankiewicz L, Ołdziej S, Grzonka Z, Abrahamson M, Grubb A, Brömme D. (2002) Azapeptides structurally based upon inhibitory sites of cystatins as potent and selective inhibitors of cysteine proteases. J Med Chem.; 45: 4202-11.

Wijffels GL. (1998) Cathepsin B. In Handbook of Proteolytic Enzymes. Barrett AJ, Rawlings ND, Woessne, JF. eds, pp 609-17. Academic Press, San Diego, London, Boston, New York, Sydney, Tokyo, Toronto.

Yamamoto A, Tomoo K, Hara T, Murata M, Kitamura K, Ishida T. (2000) Substrate specificity of bovine cathepsin B and its inhibition by CA074, based on crystal structure refinement of the complex. J Biochem.; 127: 635-43.

Zore I, Krasovec M, Cimerman N, Kuhelj R, Werle B, Nielsen H, Brunner N, Kos J. (2001) Cathepsin B/cystatin C complex levels in sera from patients with lung and colorectal cancer. Biol Chem.; 382: 805-10. 